\title{
Konsep Sedekah Bergulir untuk Pemberdayaan Masyarakat Duafa
}

\author{
Uki Masduki', Yayat Sujatna², Imal Istimal3 \\ 1,2,3Institut Teknologi dan Bisnis Ahmad Dahlan \\ Email: ukay.albantani@gmail.com \\ DOI: $10.18196 / p p m .32 .200$
}

\begin{abstract}
Abstrak
Tingginya kepedulian sosial masyarakat Indonesia melalui infak atau sedekah ternyata tidak cukup dalam menyelesaikan permasalahanpermasalahan masyarakat, seperti kemiskinan. Sedekah yang diberikan biasanya hanya untuk memenuhi kebutuhan konsumtif sesaat, bukan untuk kebutuhan produktif yang dapat dirasakan penerima dalam waktu jangka panjang. Sedekah seharusnya mampu memberdayakan penerima sehingga dapat keluar dari permasalahannya dan berubah statusnya menjadi pemberi sedekah. Agar sedekah yang diberikan dapat bermanfaat lebih banyak, perlu pengelolaan yang memiliki orientasi pemberdayaan jangka panjang, di antaranya melalui sedekah bergulir. Tujuan kajian ini adalah mengkaji konsep sedekah bergulir untuk pemberdayaan masyarakat duafa. Metode kajian menggunakan pendekatan kajian lapangan. Pendekatan ini mengacu pada konsep penelitian lapangan, yaitu mempelajari secara intensif tentang latar belakang keadaan sekarang dan interaksi suatu sosial, individu, kelompok, lembaga, dan masyarakat. Hasil kajian ini menyimpulkan dan merekomendasikan bahwa dalam upaya mengatasi permasalahan ekonomi masyarakat dapat dilakukan melaui sedekah bergulir.
\end{abstract}

Kata Kunci: duafa, filantropi, pemberdayaan, sedekah bergulir

\section{PENDAhULUAN}

Sebagai negara berkembang, Indonesia masih memiliki banyak masalah dengan kemiskinan. Data resmi BPS menunjukkan pada tahun 2019 jumlah kemiskinan di Indonesia mencapai 24,97 juta orang atau setara dengan 9,22 persen dari total penduduk Indonesia. Data ini hanya mengalami penurunan 0,9 persen dari tahun sebelumnya. Tahun berikutnya (Maret 2020) mengalami peningkatan menjadi 9,78 persen atau setara dengan 26,47 juta jiwa akibat dari pandemi Covid-19. Standar kemiskinan yang digunakan mengacau pada standar garis kemiskinan nasional, yaitu sebesar Rp 400.000 per orang per bulan. Artinya, setiap penduduk yang berpenghasilan di bawah Rp 400.000 dapat dikategorikan penduduk miskin. Tingkat kemiskinan ini lebih banyak jumlahnya jika menggunakan standar Bank Dunia, yaitu sebesar U\$3,2 per kapita per hari. Jika mengacu standar Bank Dunia, jumlah penduduk miskin di Indonesia bisa mencapai 30 persen lebih.

Pada sisi lain, Indonesia juga merupakan negara dengan jumlah pekerja pada sektor informal paling tinggi. Pekerja sektor informal merupakan pekerja mandiri, baik sebagai pelaku usaha maupun pekerja lepas. Contoh pekerja di sektor informal sebagai pelaku usaha adalah pedangan kaki lima, pedagang asongan, warung atau pedagang kecil lainnya. Sementara pekerja sektor informal sebagai pekerja lepas adalah buruh harian, tukang ojek, sopir angkot, dan lain-lain. Sektor informal juga dapat didefinisikan sebagai kegiatan ekonomi skala kecil (Mahendra, 2018). Jika dibandingkan dengan pekerja pada sektor formal, jumlahnya jauh lebih tinggi. Badan Pusat Statistik (BPS) melansir jumlah pekerja sektor informal pada tahun 2019 mencapai 70,49 juta orang. Sementara pekerja formal hanya 56,02 juta orang. 
Di antara karakteristik pekerja informal adalah (Nasution, 2016) keterbatasan modal, rendahnya akses ke lembaga keuangan, rendahnya manajemen usaha, kurang diperhatikan oleh pemerintah, bahkan dianggap pihak yang mengganggu ketertiban. Padahal, sektor informal memiliki peran yang cukup berarti dalam menciptakan kesempatan kerja dan mengatasi masalah pengangguran serta mendorong tumbuhnya wairausahawanwirausahawan baru (Suyadi, 2017). Pekerja pada sektor informal merupakan kelompok marginal (duafa) yang bisa dipastikan penyumbang terbesar bagi tumbuhnya kemiskinan. Dalam kelompok ini juga banyak orang yang berusia tidak produktif dan tidak memiliki rumah sehingga rentan menjadi pengangguran, bahkan menjadi pengemis.

Meskipun jumlah kaum atau kelompok marginal banyak di Indonesia, kelompok dengan tingkat kesalehan sosial juga tinggi. Kesalehan ini merupakan ekspresi dan praktik perilaku orang-orang Islam yang peduli terhadap nilai-nilai Islam secara sosial, seperti halnya menyumbang dana bantuan berupa infaq, shadaqah, dan amal jariyah. Munculnya praktik kesalehan sosial tersebut merupakan bentuk ekspresi filantropis dan juga spiritualis yang hendak dilakukan kelas menengah muslim Indonesia (Wasisto, 2015). Perilaku ini menurut Aristoteles karena manusia sebagai zoon politicon. Para filsuf muslim dahulu menyebutnya al-insan madaniyy bith-thab'i yang keduanya memiliki arti bahwa manusia adalah makhluk sosial (Purwanto, 2014). Perilaku ini juga sebagai bentuk kesadaran masyarakat akan perlunya menggabungkan diri dalam kelompok-kelompok filantropi untuk bersama-sama menyelesaikan masalah kemiskinan dan meningkatkan kesejahteraan masyarakat, baik yang terdapat di sekeliling lingkungan terdekat maupun masyarakat yang jauh (Latief, 2010).

Bukti bahwa masyarakat Indonesia memiliki nilai kesalehan sosial dapat dilihat dari banyaknya lembaga filahtropi berdiri serta kuantitas nilai sumbangannya (infak dan sedekah). Lembaga filantropi hadir didorong oleh kekuatan religiusitas (keagamaan) yang bersumber dari agama Kristen atau Islam. Kehadirannya memiliki visi dakwah dengan penyediaan pelayanan sosial, terutama pendidikan, kesehatan, dan kesejahteraan sosial (panti-panti sosial) (Jusuf, 2017). Selain itu, gerakan filantropi saat ini masih identik dengan upaya penguatan modal sosial dan pemberdayaan masyarakat. Gerakan tersebut merupakan respons dari realisasi pembangunan prorakyat yang selama ini belum optimal dilakukan oleh pemerintah (Abidin, 2012). Oleh karena itu, kehadiran organisasi atau lembaga filantropi mampu menjawab problematika program pemerintah yang sifatnya temporer (Bahjatulloh, 2016). Lembaga filantropi familiar di Indonesia adalah Dompet Dhuafa, Lazismu, Pos Kemanusiaan Peduli Umat (PKPU), Lazisnu, dan lain-lain.

Selain melalui lembaga filantropi, kesalehan sosial masyarakat Indonesia juga terlihat dari berbagai sumbangan yang bersifat temporer, seperti penyaluran bencana (atau masalah individu/pribadi lainnya) yang notabene dana sumbangannya tidak sedikit. Nilai sumbangan untuk masalah individu yang mudah dilihat seperti melalui kitabisa.com. Kitabisa.com merupakan portal yang didirikan untuk mempertemukan masyarakat penerima sedekah (sumbangan) dan pemberi sumbangan. Target capaian sumbangan melalui portal ini selalu tercapai, bahkan melebihi target meskipun yang dibutuhkan sampai ratusan juta rupiah. Fenomena lembaga filantropi dan tingginya tingkat kepedulian masyarakat terhadap sesamanya merupakan bukti bahwa masyarakat Indonesia memiliki kesalehan sosial yang 
tinggi. Jika peluang ini dikelola dengan baik, Hal ini akan berdampak pada penguatan ekonomi dan penyelesaian masalah ummat.

Melihat banyaknya lembaga filantropi dan tingkat kesalehan sosial masyarakat Indoensia melalui kepedulian terhadap sesama, semestinya permasalahan klasik yang ada di Indonesia seperti kemiskinan mudah diatasi, tetapi kenyataannya tidak demikian. Ada dua bentuk filantropi (kedermawanan) menurut Yusuf (2007), yaitu filantropi tradisional dan filantropi modern. Filantropi tradisional adalah filantropi yang berbasis karitas (Charity) atau belas kasihan. Pada umumnya, Filantropi berbasis karitas ini berbentuk pemberian untuk kepentingan pelayanan sosial, seperti pemberian para dermawan kepada kaum miskin untuk membantu kebutuhan makanan, pakaian, tempat tinggal, dan lain-lain. Sementara filantropi modern atau lazim disebut filantropi untuk pembangunan sosial dan keadilan sosial merupakan bentuk kedermawanan sosial yang dimaksudkan untuk menjembatani jurang antara si kaya dan si miskin. Di Indonesia, filantropi lebih banyak dilakukan dengan pendekatan tradisional sehingga pemberian hanya untuk kebutuhan konsumtif (sehari-hari) bukan untuk produktif yang dapat dirasakan dalam waktu jangka panjang.

Model filantropi tradisional ini perlu diubah orientasinya, dari hanya sekadar konsumtif (kebutuhan sesaat) diarahkan pada kebutuhan produktif,seperti untuk membuka usaha atau penambahan modal usaha. Pola sedekah tradisional ini tidak begitu berpengaruh pada perbaikan penerima untuk jangka panjang. Dana sedekah seharusnya diberikan untuk kebutuhan produktif agar penerima kuat perekonomiannya dan tidak lagi menjadi penerima sedekah, tetapi berubah menjadi pemberi sedekah. Di sinilah pentingnya inovasi lembaga sedekah yang mengarahkan pada pemberdayaan penerima sedekah, salah satunya melalui sedekah bergulir.

\section{METODOLOGI}

Metodologi kajian ini adalah dengan pendekatan kajian lapangan. Pendekatan ini mengacu pada konsep penelitian lapangan Usman dan Akbar (2008), yaitu mempelajari secara intensif tentang latar belakang keadaan sekarang, dan interaksi sosial, individu, kelompok, lembaga, serta masyarakat. Dalam konteks kajian ini, penelitian analisis dilakukan dengan mengamati fenomena sedekah yang berlangsung di masyarakat, baik dari pihak pemberi sedekah maupun penerima sedekah, termasuk pengelolaan dana sedekah di masyarakat. Kajian ini juga dapat dinyatakan sebagai kajian dengan teknik pengumpulan data melalui non participant observation.

\section{HASIL DAN PEMBAHASAN}

\section{Konsep Sedekah Bergulir}

Sedekah atau filantropi dapat diklasifikan ke dalam dua bentuk, yaitu filantropi tradisional dan filantropi modern. Filantropi tradisional dilakukan secara individu sebagai wujud belas kasihan melalui pemberian kebutuhan pokok yang bersifat jangka pendek. Sementara Filantropi modern merupakan bentuk kedermawanan sosial yang dimaksudkan untuk menjembatani jurang antara si kaya dan si miskin (Yusuf, 2007). Filantropi modern 
dapat diwujudkan dalam pendirian lembaga zakat, infak, dan sedekah (ZIS). Sementara filantropi tradisional sering dipraktikkan oleh individu atau masyarakat dengan memberikan sedekah/sumbangan langsung kepada yang dianggap membutuhkan.

Baik filantropi modern maupun tradisional memiliki kelebihan dan kekurangan. Kelebihan filantropi tradisional adalah sumbangan dapat dirasakan langsung oleh penerima, sementara kelemahannya ialah tidak ada upaya pemberdayaan dan bersifat jangka pendek sehingga masalah yang dihadapi penerima sulit teratasi. Sementara kelebihan filantropi modern adalah sumbangan ini dikelola secara profesional dan berupaya memberikan edukasi serta pemberdayaan kepada penerima, tetapi kelemahannya ialah sumbangan ini sulit menjangkau penerima yang lebih luas sehingga penerima yang sangat membutuhkan saat itu juga tidak bisa diakomodasi. Meskipun demikian, baik filantropi modern maupun tradisional memiliki peran yang berarti dalam mengatasi permasalahan ekonomi duafa. Atas dasar kelebihan dan kelemahan filantropi tersebut, agar dana sedekah lebih efektif dan produktif, perlu ditemukan konsep sedekah produktif, misalnya melalui sedekah bergulir.

Sedekah bergulir menekankan pada efektivitas pemanfaatan dana sedekah dalam jangka panjang oleh penerima dana sedekah. Sedekah yang diberikan atau diterima akan gulirkan kembali atau diberikan kembali kepada pihak lain yang berhak menerima. Dengan demikian, sedekah yang diterima sifatnya "pinjaman" yang harus dikembalikan. Dengan demikian, dana sedekah yang diberikan tidak hilang begitu saja (hanya untuk kebutuhan konsumtif sesaat), tetapi dana tersebut akan memberikan manfaat bagi dirinya dan orang lain dalam jangka panjang. Setiap dana sedekah yang diberikan akan terus mengalir sepanjang masa dan memberikan manfaat kepada banyak orang. Setidaknya ada tiga unsur (pihak) yang harus dipenuhi agar sedekah bergulir efektif, yaitu pemberi sedekah, penerima sedekah, dan lembaga sedekah begulir.

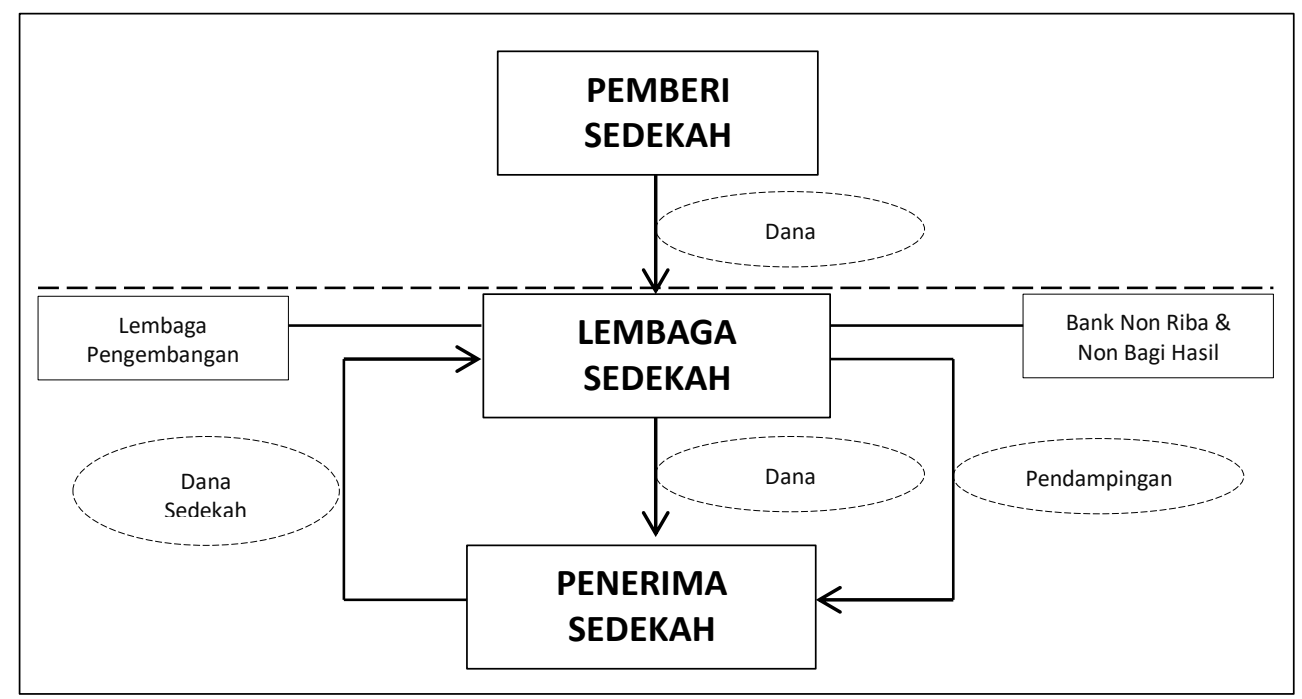

\section{Pemberi Sedekah}

Gambar 1. Konsep Sedekah Bergulir

Pemberi sedekah adalah pihak surplus, baik individu, perorangan, maupun kelompok yang secara kolektif memberikan dana sedekah berupa materi (uang). Bagi perorangan, sedekah diberikan langsung kapan saja kepada lembaga sedekah bergulir dengan besaran 
dana sesuai kemampuan. Sementara kelompok adalah pemberi sedekah secara kolektif yang dikoordinasikan oleh lembaga atau perusahaan. Besarnya dana dari kategori pemberi kelompok sesuai komitmen yang diambil dari honor/gaji pemberi sedekah setiap bulan. Pemberian sedekah secara kolektif ini dilakukan melalui lembaga/perusahaan.

\section{Penerima Sedekah}

Penerima sedekah adalah masyarakat duafa secara individu yang memenuhi syarat sebagai penerima sedekah bergulir. Penerima sedekah adalah masyarakat duafa produktif, baik yang telah memiliki usaha untuk dikembangkan maupun yang belum memiliki usaha. Syarat dan karakteristik penerima sedekah bergulir sebagai berikut.

1. Masyarakat duafa dapat dipertimbangkan dengan melihat kondisi rumah, pendapatan, atau kondisi hidup.

2. Memiliki usaha skala kecil (pendapatannya hanya untuk kebutuhan sehari-hari) atau belum memiliki usaha, tetapi mempunyai komitmen untuk menajalankan usaha.

3. Tidak memiliki akses ke lembaga keuangan atau tidak bankable.

4. Memiliki komitmen untuk "mengembalikan" dana sedekah dan komitmen bersedekah sebagai tambahan pada pengembalian "pokok pinjaman".

5. Contoh penerima sedekahanatar lain pedagang asongan, pengemis, difabel, janda, buruh, atau pengangguran yang tidak memungkinkan diserap oleh lapangan kerja. Apabila diberikan sedekah, hal ini akan meningkatkan taraf hidupnya atau berkembang usahanya.

6. Penerima ditentukan oleh lembaga pengelola sedekah atau ditentukan oleh masyarakat umum.

\section{Lembaga Sedekah Bergulir}

Lembaga sedekah bergurir memiliki peranan yang sangat penting dalam membantu efektivitas sedekah bergulir. Lembaga ini berperan sebagai perantara bagi pemberi sedekah dan pembimbing bagi penerima sedekah. Dengan demikian, dana sedekah dapat bergulir dan memberikan manfaat yang lebih luas, lebih baik, dan lebih bermakna, baik bagi pemberi maupun penerima sedekah.

Tugas lembaga sedekah bergulir adalah selain menghimpun dana dari masyarakat dan menyalurkan kembali kepada yang berhak, juga sebagai lembaga pendamping, khususnya bagi penerima. Hal ini bertujuan agar sedekah yang diterima dapat memberikan manfaat dan nilai tambah. Dengan begitu, dana sedekah dapat digulirkan kembali. Biaya operasional lembaga sedekah bergulir dapat mengacu pada pengelolaan lembaga ZIS.

\section{Prinsip-Prinsip Sedekah Bergulir}

Agar sedekah bergulir berjalan efektif, perlu prinsip-prinsip yang harus dijalankan lembaga sedekah bergulir, yaitu

1. Profesional

Lembaga sedekah bergulir harus dikelola oleh pihak yang memiliki kompetensi pengelolaan dana sedekah (ZIS) dan pendampingan usaha serta berkomitmen dalam pemberdayaan masyarakat. Lembaga sedekah juga harus memiliki target capaian pemberi dan keberhasilan penerima. 
2. Transparan

Pengelolaan sedekah bergulir dilakukan secara transparan, akuntabel, serta pemberi dan penerima diketahui oleh masyarakat luas. Laporan pengelolaan dana sedekah bergulir dilakukan secara berkala dan/atau real time melalui aplikasi atau situs website.

3. Komitmen Pemberdayaan

Lembaga sedekah bergulir merupakan organisasi nirlaba. Oleh karena itu, harus memiliki komitmen untuk membantu menyelesaikan masalah ekonomi masyarakat penerima. Keberhasilan lembaga dilihat dari seberapa besar dana sedekah yang dimanfaatkan, seberapa besar penerima sedekah, dan seberapa besar tingkat keberhasilan sedekah bergulir. Keberhasilan lembaga tidak dilihat dari seberapa besar dana sedekah yang diterima.

4. Melibatkan Masyarakat Luas

Keberhasilan sedekah bergulir dapat dicapai dengan banyak keterlibatan masyarakat dalam mendukung sedekah bergulir, baik secara langsung sebagai pemberi/penerima maupun tidak langsung sebagai pendukung, termasuk menentukan penerima sedekah.

\section{KESIMPULAN}

Permasalahan ekonomi yang banyak dihadapi oleh masyarakat harus di atasi dengan banyak alternatif dan dukungan dari berbagai pihak, baik pemerintah maupun masyarakat luas. Salah satu alternatif yang dapat dijalankan dalam mengatasi persoalan ekonomi masyarakat, khususnya kaum duafa adalah dengan sedekah bergulir melalui lembaga sedekah bergulir. Sedekah bergulir adalah sedekah yang diberikan kepada yang berhak menerimanya sebagai "pinjaman" kemudian dikembalikan sesuai besaran yang diterima dengan komitmen atau tambahan uang sedekah semampunya. Sedekah bergulir dapat berjalan dengan efektif apabila dijalankan oleh lembaga nirlaba yang memiliki kompetensi dan komitmen dalam pemberdayaan serta adanya dukungan dari masyarakat luas, termasuk pemerintah.

\section{REFERENSI}

Abidin, Z. (2013). Manfestasi dan Latensi Lembaga Filantropi Islam dalam Praktik

Pemberadayaan Masyarakat: Studi di Rumah Zakat Malang. Jurnal Salam, 15 (2)

Bahjatulloh, Q. M. (2016). Pengembangan Pemberdayaan Ekonomi Masyarakat Melalui

Kegiatan Filantropi (Studi Kasus Lembaga Tazakka DIII Perbankan Syariah IAIN

Salatiga). INFERENSI: Jurnal Penelitian Sosial Keagamaan, 10(2), 473-494.

Jusuf, C. (2007). Filantropi Modern untuk Pembangunan Sosial. Sosio Konsepsia, 12(1), 74-

80.

Latief, H., (2010). Melayani Umat: Filantropi Islam dan Ideologi Kesejahteraan Kaum

Modernis, Jakarta: Gramedia Pustaka Utama

Mahendra, S. (2018). Keterkaitan Modal Sosial dengan Strategi Kelangsungan Usaha

Pedagang Sektor Informal di Kawasan Waduk Mulur: Studi Kasus Pada Pedagang

Sektor Informal di Kawasan Waduk Mulur Kelurahan Mulur Kecamatan Bendosari

Kabupaten Sukoharjo. Jurnal Analisa Sosiologi, 4(2).

Nasution, A. P. (2016). Pemberdayaan Sektor Ekonomi Informal: Suatu Tinjauan

Empiris. Jurnal Dimensi, 4(2). 
Purwanto, Y. (2014). Memaknai Pesan Spiritual Ajaran Agama Dalam Membangun Karakter Kesalehan Sosial. Jurnal Sosioteknologi, 13(1), 41-46.

Suyadi, B. (2017). Peranan sektor informal dalam penyerapan tenaga kerja dan peningkatan pendapatan nelayan di wilayah pantai pasir putih situbondo. Jurnal pendidikan ekonomi: Jurnal Ilmiah Ilmu Pendidikan, Ilmu Ekonomi dan Ilmu Sosial, 10(2).

Usman, H., dan Akbar, P., S., 2008. Metodologi Penelitian Sosial. Jakarta: Bumi Aksara

Wasisto, J. R. (2015). Kesalehan sosial sebagai ritual kelas menengah muslim. IBDA: Jurnal Kajian Islam dan Budaya, 13(2), 145-157. 